only the homes of these two renowned men, but also some at least of the countryside which they knew and loved, are safe from future change though suburban London lies so near.

\section{Jubilee of the Pasteur Institute, Paris}

November 14, 1938, marked the fiftieth anniversary of the inauguration of the Pasteur Institute of Paris as the result of international subseription, but the actual celebrations have, owing to the recent crisis, been postponed until December 27, the anniversary of the birth of Pasteur. The spacious building in the Rue Dutot, recently re-named Rue du Dr. Roux, took the place of the small laboratory in the Rue d'Ulm where so much of Pasteur's valuable work had been carried out. Although his labours were interrupted by ill-health during the rest of his life, he received the assistance of a number of collaborators and pupils, notably Roux, Yersin, Metchnikoff, Chamberland and Calmette. The institute at once became an important centre for bacteriological research, the results of which were published in the Annales de l'Institut Pasteur, founded in 1887, in which epoch-making papers appeared on rabies, anthrax, diphtheria toxin and antitoxin, and experimental syphilis, among many other important subjects.

IN 1903 the Annales were supplemented by the Bulletin de l'Institut Pasteur, which contained, as the title indicated, reviews and summaries of work on bacteriology, medicine, general biology, physiology and biological chemistry in relation to microbiology. The close association of the Institute with clinical medicine was shown by the subsequent establishment of the Pasteur hospital for infectious diseases on the opposite side of the street. Pasteur died on September 28,1895 , and after a public funeral was laid to rest in a magnificent tomb in a crypt of the Institute. Since his death, three eminent men have been in charge of the Institute, namely, Emile Duclaux (1895-1904), Emile Roux (1904-1933) and Louis Martin, the present director. Metchnikoff, Chamberland and Calmette were for some time sub-directors. Numerous Pasteur institutes modelled on that of Paris have been built in different parts of the world, such as those at Saigon (1889), Tunis (1893), Lille (1895), Algiers (1910) and Athens (1920).

\section{Violent Earthquake of November Io}

IT is reported from the Air Ministry that an earthquake of great violence was recorded on November 10 at Kew Observatory at 20 h. 30 m. 7 s. G.M.T., a second movement following about half an hour later. The displacements of the ground at Kew were about one tenth of an inch, and the epicentre of the shock was 5,100 miles away. This earthquake has been reported from observatories throughout the world. From New York it appeared to be at a distance of 3,400 miles and from Pasadena where the needles nearly went off the paper of the recording seismographs it appeared to be 2,550 miles. From the Dominion Observatory, Wellington, New Zealand, the epicentre appeared to be distant 6,000 miles, and from the Villa Ortoza Observatory in the Argentine more than 6,000 miles. At Mr. J. J. Shaw's Observatory at West Bromwich, it was reported to have had the largest amplitudes recorded in thirty years and to have been of greater violence than the Quetta earthquake of 1935 or the Tokyo earthquake of 1923. The shock was felt by people in Alaska though no damage was done, and it is reported in the Yorkshire Post to have been felt in Leeds. A small seismic sea wave was apparent on some of the Hawaiian Islands. All this evidence seems to point to a submarine epicentre in the North Pacific Ocean near the Aleutian Islands and to the south-west of Alaska. This area is known to be one of the unstable regions of the earth, about fifty large and many more small earthquakes being recorded from the vicinity between 1913 and 1930 .

\section{Earthquake near Vienna}

AN earthquake, with an epicentre near Vienna, occurred about 4h. G.C.T. on November 8, doing some damage to property, but causing no casualties. An earthquake in this region is most unusual, and the last one of any importance was in 1927 on October 8 at 19h. $48 \mathrm{~m}$. 55s. G.C.T. with epicentre lat. $48^{\circ} 04^{\prime}$ N., long. $16^{\circ} 35^{\prime} \mathrm{E}$. It was discussed very thoroughly by Dr. V. Conrad, of Vienna, who confirmed from the records the existence of the $P^{*}$ and $S^{*}$ waves. $\mathrm{He}$ considered that the depth of focus was near $30 \mathrm{~km}$., and that the thickness of the Granitic layer in this region was of the order of $40 \mathrm{~km}$. Further, Conrad found a pulse which he thought was caused at the A. Mohorovičić discontinuity $60 \mathrm{~km}$. deep under the earth's surface. It will be interesting to see whether or not these findings are confirmed by the present shock.

\section{Inventors and Inventions}

Sor JAmes Swinburne, in his presidential address delivered on October 25 to the Institute of Plastics, discussed the subject of invention. In his opinion, inventions are usually the work of men less than forty years of age and often are discovered by those without scientific training. $\mathrm{He}$ attributed this apparent anomaly to the likelihood of the technical man allowing his thought to be constrained in narrow grooves. The specialization of the modern world works against the interests of the home inventor. The day of the lone inventor has passed and progress is now usually the result of co-ordinated efforts of large research departments. Some of the greatest inventions have been, as a far-seeing judge once put it, what any fool might have done, but had not. Differentiating between the independent or outside inventor and the inside or technical man, Sir James believes that the latter is the former's chief enemy. When the independent worker approaches a commercial concern with an invention, he meets with opposition from the technical representative of the company, who is inspired by the human instinct of self-preservation, for the device submitted is something which the staff man feels that he himself ought to have thought of. A further distinction was drawn between the qualities necessary for an executive and 
those for a technical man. Sir James epigrammatically stated that the object of patent law is to help industry by encouraging progress, by checking progress at each step ; in other words, if there were no patent law and invention continued at its present rate, industry would progress faster; on the other hand, if there were no rewards for invention, the incentive to invent would almost disappear. In his opinion, the cost of patents is too high, and the legal expense entailed in fighting an infringement favours the large company. The appeal system gives rise to anomalies. Thus, the first judge may decide against a patentee, the appeal judges may agree with him, and finally three out of five in the Lords of Appeal might uphold the patentee's claim. We then have the curious position of three judges overruling six.

\section{History of Iron Founding in England}

AT the annual general meeting of the Newcomen Society on November 9, Mr. W. A. Young was elected president for the ensuing year. The membership of the Society now stands at 870. After the conclusion of the business, the first part of a paper by Mr. Rhys Jenkins was read entitled "Iron-founding in England, 1490-1890". Though there are objects of cast-iron to be seen in museums, probably made $1,500-2,000$ years ago, iron-founding in Europe as a regular trade is of comparatively modern origin. In Great Britain iron-founding followed the substitution of the primitive hearth, the bloomery, by the high furnace, known as the blast furnace. Sussex was the cradle of English iron-founding and there is a reference dated 1490 to a payment on behalf of the Archbishop of Canterbury to "ye Ierne founders of Buxstede". The industry was based mainly on the production of war material, though there was a certain amount of production of chimney backs, fire dogs and grave slabs, and also of gear for the forges. King Henry VIII came to the throne in 1509 and he at once set about the provision of armament. He brought over foreign workmen to cast bronze guns, and a year or two prior to his death the first cast-iron guns were made. The credit for initiating this departure belongs to William Levet, the parson of Buxted. In the early days of Elizabeth, an export trade in cast-iron guns commenced. Guns were sent to the Low Countries, France and Germany, and in 1582 Portugal took no fewer than 132 pieces. In 1601 it was stated the total output was about 800 tons per annum. The earliest account of any real value of the methods of casting guns is given by Sirurey de Saint Remy in his "Memoires d'Artillerie" published in Paris in 1693 .

\section{Structure and Strength}

The seventh Andrew Laing Lecture, delivered by Sir William Bragg before the North-East Coast Institution of Engineers and Shipbuilders at Newcastle on November 8 , dealt with the molecular basis of the strength of materials. Taking carbon compounds first, he showed how the regular arrangement of the carbon atoms in the diamond as determined by modern $\mathrm{X}$-ray analysis accounts for its hardness, how long chains of such atoms with side atoms of hydrogen lead to paraffins, the tendency of which to set themselves parallel to each other like corn stalks in a field leads to their slipperiness, and how chains modified by oxygen atoms at one end lead to oils with lubricating powers. Another arrangement of carbon atoms in a plane leads to graphite sheets, which again can slide over each other and also possess lubricating powers. More complicated chain structures give celluloses of many kinds as found in plants, and a combination of benzene rings with oxygen gives plastics like bakelite. The atoms of metals and alloys are in general packed together like spheres, and the properties of the product depend mainly on the sizes of the atoms constituting it and the number of electrons they can put into the common stock.

\section{The Science Museum: Recent Acquisitions}

THE inventor's working model of the first calculating machine capable of multiplying sums of money in sterling currency (f.s.d. and fractions of a penny) has been presented to the Science Museum. The present machine, invented by Mr. E. C. McClure in 1934, requires only one turn of the handle for each digit in the multiplier, so that to multiply any sum of money by a number less than a thousand it is necessary to make only three turns of the handle. The principles embodied in the machine are being used in a new sterling multiplying punch which is being manufactured by Messrs. Powers-Samas Accounting Machines Ltd., who have given the model to the Science Museum. A collection of trade cards issued by English instrument makers to advertise their products, presented by Mr. Thomas H. Court, has recently been placed on exhibition; they are mostly of the eighteenth century and are of considerable historical interest and importance. The Museum has acquired a large-scale working model of the escapement employed about 1880 in the original Waterbury watches, which were among the first really cheap watches to be made. The group of hearing aids illustrates developments since 1930; of special interest are the widely contrasting valve amplifying sets of 1932 and 1938 .

\section{Radio Valve Data}

$\mathrm{EACH}_{\mathrm{ACH}}$ year the Wireless World performs a very useful function in providing comprehensive details of all the thermionic valves available in Great Britain. The issue of November 10 contains a Valve Data Supplement listing more than 1,000 different valves in twenty pages of tables. All types of valves are dealt with, whether these be used as rectifiers, frequency changers or amplifiers ; and while some of those described may be becoming obsolete, it is necessary to include them as they are used for replacement purposes in existing radio sets or amplifiers. In general, the valves are listed in order of filament or heater voltage, and the variation in this voltage is one of the reasons for the large number of valves it is necessary to describe. Valves for battery operation have filaments for 2-volt working, while 